\title{
Development Strategies on Taking Thailand's Health Promotion Related Tourism Business into the Global Market
}

\author{
Sinee Sankrusme \\ Correspondence: Sinee Sankrusme, Department of International Business, Faculty of Business Administration, \\ Ramkhamhaeng University, Thailand. E-mail: sinee7@gmail.com
}

Received: March 19, 2012

Accepted: August 28, 2012

Online Published: October 16, 2012

doi:10.5539/ibr.v5n11p83

URL: http://dx.doi.org/10.5539/ibr.v5n11p83

\begin{abstract}
The Royal Thai Government has made it a policy to promote Thailand as the Spa Capital of Asia since 2004. The Ministry of Public Health, in conjunction with the Office of the National Economic and Social Development Board has adopted a five-year plan (2009-2013) to promote the health service business to turn Thailand into a World-Class Spa Destination with the cooperation of both the public and private sectors. The objectives of this study are to analyze the market regarding the promotion of health-related tourism (spas), the potential supply and demand, consumer behavior and visitors' satisfaction relating to the use of the country's spa services, strategies for the development and promotion of health-related tourism businesses (spas), the obstacles to achieving this objective, and suggestions with regard to the latter. The population of the study consisted of foreign nationals who used spa services in Prachuabkirikhan, Phuket, Phanga and Krabi provinces, with 100 samples taken from each province. The research methodology used in this study is both qualitative and quantitative in nature, in addition to which a descriptive approach was also adopted. The results demonstrate that, although spas were relatively well known among foreign tourists during 1993-1994, the spa business has enjoyed a boom from 2001 down to the present. The study analyzed both demand and supply of spa business. Most of the foreign nationals interviewed stated that they visited spas during their vacation time and stressed the importance of visiting a spa in planning their travel itinerary. In their opinion, compared with the best spa facilities in Asia, spas in Thailand would prove cheaper. The category of spa that was used the most that was the resort spa. With regard to the atmosphere of the spa itself, the majority favored a natural atmosphere. As for their favorite products, they used proprietary products belonging to the spa service center. Concerning the services the spa offered, they liked body massage the most. As regards their reasons for selecting a particular spa's services, they did so in accordance with the quality and standard of service. For most of the respondents, their objective in using the services of a spa was to relieve pain in their muscles. It was found that tourists expressed a high degree of satisfaction with regard to their use of the spa's services and as well as the overall circumstances pertaining to such spas. As far as the strategies for the development of this sector are concerned, these need to focus on management, market planning, competition, marketing and public relations, successful spa factors, and the export market. On the other hand, strategies need to be devised pertaining to the development and supervision of standards, export promotion and spa development. Also included are strategies relating to quality service and customer satisfaction. Clearly, the strengths of this sector would form the foundation of the sales strategies, while efforts should be made to eliminate or improve upon any weaknesses to be found in this business.
\end{abstract}

Keywords: development strategy, health promotion tourism, global market

\section{Introduction}

Given the rapid changes to which modern-day society is being subjected, an increasing number of people are suffering from stress, and their physical and mental health has deteriorated. As a result, more and more people are beginning to weigh the increasing importance of health care. However, due to the tendency on the part of the younger generation to focus on self-gratification and ease of accessibility to facilities, health care service centers are playing an increasingly important role in their daily life and arousing increasing interest, particularly "spas". Spa services have mushroomed in business areas and prominent travel destinations, whether these happen to be in the capital itself or in the provinces, the concept being to provide health-related services in a variety of forms. Spa service centers are located in hotels or at various resorts scattered throughout the main travel destinations across the country and are able to attract foreign tourists and generate a sizeable amount in revenue for Thailand as a whole. Since this is in line with the strategy to develop Thailand as a medical hub of the Asian region, it is 
appropriate, therefore, to study the adoption of an appropriate business development plan.

\section{Objectives}

1. To study the market with regard to the promotion of health-related tourism businesses (spas)

2. To study the potential regarding supply and demand

3. To study the behavior of consumers and their satisfaction with regard to using spa services

4. To study development strategies relating to the promotion of health-related tourism businesses (spas)

5. To study the obstacles facing such businesses and make pertinent suggestions in this regard

\section{Literature Review}

Due to people worldwide wish a good health, less stress and happiness in their life, health promotion tourism is then being one of alternatives to service tourists. It, later, creates the growth of various businesses, for instance, spa business. Therefore, there are many spa businesses which increase revenue to Thailand. This causes researchers being interested in the study of spa businesses in order to develop Thailand's health promotion tourism to meet universal standard. Mhunkham (2008) - Since Thailand's policy determines to push Thai spa as "Spa of Asia” Spa, therefore, creates a rapid expansion and a manner of jumping growth as well as steps to develop to meet international standard. Boonroong (2007) studied the current popularity in health care by using the nature for therapy to adjust body balance and release the stress. It, later, creates spa business to be popular in both Thai people and foreigners. Pothisathian (2005) - Since there is a variety concepts of health promotion. These, therefore, creates spa business service involving health and beauty such as spa, centers of health and beauty, places of massage, point pressing and implanting of needles including taking care and encouragement of health to be strong and perfect freeing from illness. However, owing to the new generation life needs the most concerning convenience, health service places, then, enter and have greater roles in daily life. Spa market in Thailand still has a chance in expansion consecutively which is the result of popularity to search for alternatives to release stress aiming to be healthy. During 2001-2002, Thailand obtained revenues 85 US million dollars from foreign tourists who came to use spa services, 80 percents of spa service users calculating 3.3 million persons and approximately 230 spa places (Intelligent Spa Company Survey). These cause Thai and foreign businessmen being interested to invest. In addition, public sector such as Tourism Authority of Thailand, Department of Export Promotion, Ministry of Public Health, Office of the Board of Investment promote spa businesses by public relations aggressively. In the past, spa business operated at hotels or leading resorts. Since the matter of health became a hot issue in the past 2-3 years, this causes spa business widespread well-known among Thai people (Institute of Profession and Thai Spa Culture Encouragement, 2008). There are many types of spa as follows:

- Destination spa: People all over the world know "Chiva Som International Health Resort” which is the spa service place in world class having VIP customers from many countries such as world class millionaire, Hollywood stars, and $\mathrm{A}^{+}$tourist level.

- Hotel/Resort Spa: Deluxe hotel, both in Bangkok and provincial tourism cities, has operated service spa for scrambling foreign tourists which increase revenues in the area of residence and foods. It, therefore, has originated deluxe spa in 4-5 star hotel since 1997.

- Medical spa: It has a rapid expansion. Places that provide medical spa are Bumrungrad International Hospital, Apaibhubet Hospital and Saint Carlos Hospital, etc.

- Day Spa/City Spa-Service: Outsides hotels for upper markets and small spa for subsidiary markets, most of them, establish in the areas having foreigners reside and establish in the working areas such as Sukhumvit, Silom, Surawong, etc.

- Day Spa/City Spa: Service places outside hotels for upper markets and small spa for subsidiary markets, most of them, establish in the areas having foreigners reside and establish in the working areas such as Sukhumvit, Silom, Suriwong, etc.

Health activities increase in the percentage of 36 per year which was a good tendency. From Spa Industry Survey: Thailand 2002 (Intelligence Spas Company), it revealed that:

- Spa service increased in the percentage of 64 in the period of the past three years (2001-2004).

- Spa service users in Thailand were approximately 3.3 millions in the period of 2001-2002. In this amount, 80 percents were foreign tourists. 
In mentioning of spa in foreign countries, it is referred to spa business in the western country and in the eastern country. For spa business in the western country, people began to be interested increasingly in the matter of health. Releasing by using spa service is other alternative choices from taking exercise. Spa is a fashion of rest, releasing and maintaining strong health. Males began to have a flavor in using spa service which spa principal market in the former time was females. Spa had patterns for choice increasingly, for instance, hospital spa and hotel spa. Regarding spa business in the eastern country, Chinese began to have a favor in using spa service since 2005 which having service only in big cities such as Beijing, Shanghai or in traveling cities. In the part of Japanese, providing spa service means going to take a bath with hot mineral water in Japanese called "Onsen". Going to use spa service is a special part of life for relaxation. Tourism and the nature for therapy to obtain good health is a good way that never deteriorates since ancient time until reaching the present (Department of Export Promotion \& Data Service Center, 2008).

\section{Methodology}

The population of the study consists of foreign nationals who use spa services in Prachuabkirikhan, Phuket, Phanga and Krabi provinces, with 100 samples taken from each province. The sample consists of 400 foreigners, selecting by systematic random sampling. In addition, interviews are conducted with groups of people, namely administrators from both the public and the private sectors, representatives of tour companies and spa entrepreneurs. With regard to the data analysis, an analytic method of examining the content is used. The descriptive statistics were presented in the form of raw numbers, percentages, frequency, mean scores, and standard deviation. This study employs a combination of both quantitative and qualitative research methods.

To facilitate the data analysis, the study uses the following five-point Likert Scale to determine the various levels of satisfaction: 1 = very dissatisfied, 2 = dissatisfied, 3 = neither satisfied nor dissatisfied, $4=$ satisfied, 5 = very satisfied.

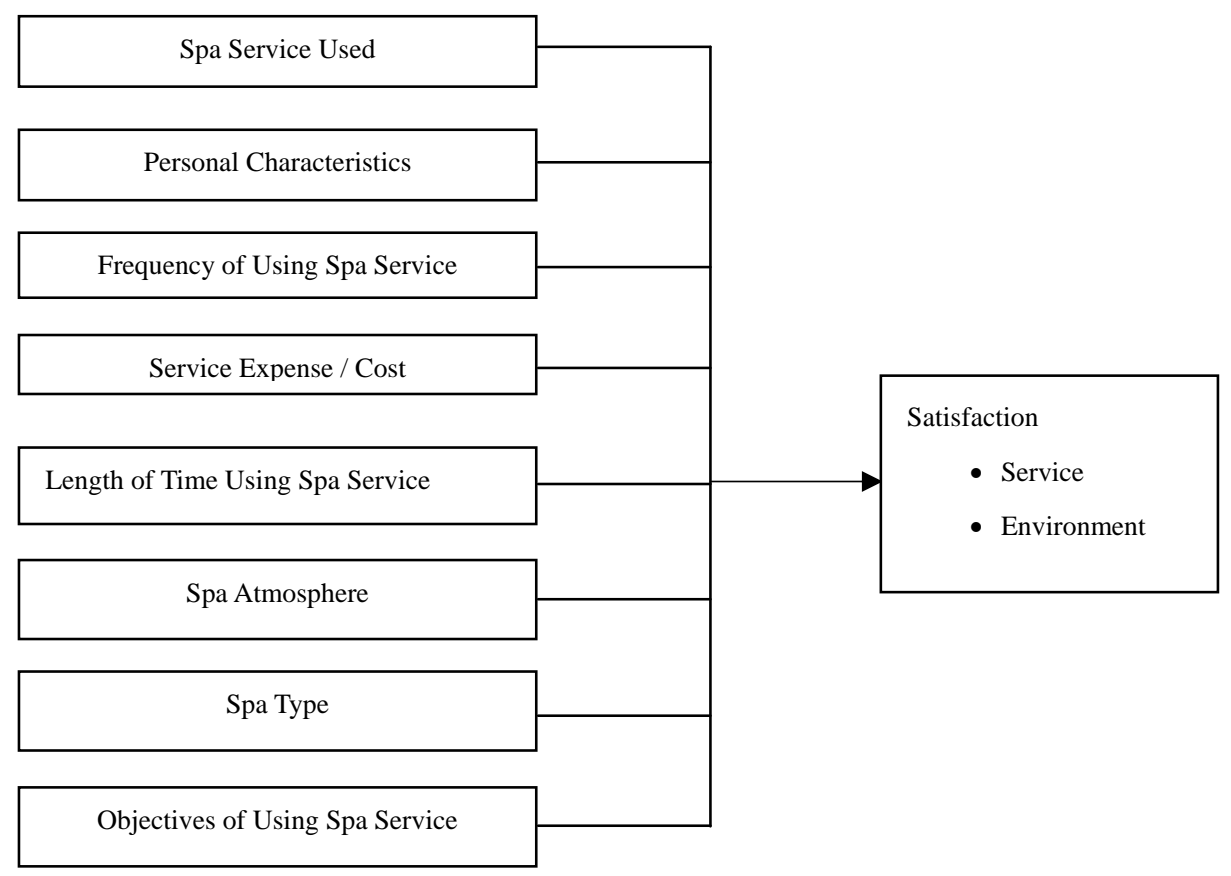

Figure 1. Framework of the Study

\section{Findings}

\subsection{Situation regarding the Market}

Health-related tourism (spas) was relatively well known among foreign tourists during 1993-1994, but it was not until 1997 that spa business began to be established in Thai hotels. Since then, Thai entrepreneurs and foreign spas had played an important role in the development of this business sector, as a result of which spas in Thailand had enjoyed somewhat of a boom from 2001 down to the present. In addition, it is the policy of the Thai government not only to promote Thailand as the medical hub of Asia but also to promote the country as the Spa Capital of Asia by upgrading such businesses to international standards. 


\subsection{Analysis of Supply and Demand}

As for the potential of supply and demand, on the demand side, this requires the provision of a quality service that is characteristically Thai, as well as beautiful natural surroundings, including distinctive tourist attractions and residences. Spas should offer a wide variety of services, which might be the western or the eastern in nature, or a blend of the East and the West, or Thai spas could offer ancient, traditional treatment as a main selling point. On the supply side, there is the good impression of the Thai national character, the low cost of living, the high standard of service, convenience, the variety of spa services available, good supplementary services, ready-made, processed herbal products. Therefore, Thailand and its spas are the leaders in this region in terms of holistic treatment due to the following factors: (1) The uniqueness of Thai massage, (2) Thai hospitality, skilled therapists, (3) Thai intellectual property, the use of Thai herbs in the treatment of sickness, (4) Tourist attractions, recreational areas and various types of holistic treatment, including spa services.

\subsection{Analysis of Consumer Behavior and Their Satisfaction}

\subsubsection{Characteristics of the Sample}

Gender. Most of sampling groups (58 percent) were female, with males accounting for the remaining 42 percent

Age. Most of the respondents (28.50 percent) were 40-44 years of age, followed by those $45-49$ years of age (16 percent). The lowest percentage (6.75 percent) was over 60 years old.

Education. Most of the respondents (49.50 percent) were educated at the bachelor degree, followed by those who had a Master's degree (26.25 percent), while those with a secondary education were the least represented (12 percent).

Occupation. Most of the respondents (34.25 percent) were employees/authorities, followed by those who were students, or teachers (21.25 percent). The lowest percentage (5.25 percent) consisted of government officials/employees of state enterprises.

Income. Most of the respondents (29.25 percent) earned between 30,001-50,000 dollars per year, followed by those who earned less 30,000 dollars per year (25 percent). Those earning over 100,000 dollars per year were the least represented (8.50 percent).

Table 1. Characteristics of Sample by Number and Percentage

\begin{tabular}{|c|c|c|c|}
\hline & Characteristics of Sample & Persons & $\%$ \\
\hline \multirow[t]{2}{*}{ Gender } & Male & 168 & 42.00 \\
\hline & Female & 232 & 58.00 \\
\hline \multirow[t]{8}{*}{ Age } & Less than 30 years old & 33 & 8.25 \\
\hline & 30-34 years old & 36 & 9.00 \\
\hline & 35-39 years old & 44 & 11.00 \\
\hline & 40-44 years old & 114 & 28.50 \\
\hline & 45-49 years old & 64 & 16.00 \\
\hline & 50-54 years old & 52 & 13.00 \\
\hline & $55-60$ years old & 30 & 7.50 \\
\hline & 60 years old and over & 27 & 6.75 \\
\hline \multirow[t]{4}{*}{ Education } & Below Bachelor's degree & 49 & 12.25 \\
\hline & Bachelor’s degree & 198 & 49.50 \\
\hline & Master's degree & 105 & 26.25 \\
\hline & Other & 48 & 12.00 \\
\hline \multirow[t]{6}{*}{ Occupation } & Business owner & 66 & 16.50 \\
\hline & Manager/Administrator & 60 & 15.00 \\
\hline & Employee/Authority & 137 & 34.25 \\
\hline & Retired & 31 & 7.75 \\
\hline & Government official/state enterprise employee & 21 & 5.25 \\
\hline & Other & 85 & 21.25 \\
\hline Annual & Under USD 30,000 & 100 & 25.00 \\
\hline \multirow[t]{4}{*}{ Income } & USD $30,001-50,000$ & 117 & 29.25 \\
\hline & USD 50,001 - 75,000 & 96 & 24.00 \\
\hline & USD 75,001 - 100,000 & 53 & 13.25 \\
\hline & Over USD 100,000 & 34 & 8.50 \\
\hline
\end{tabular}


Nationality. Most of the respondents (14 percent) were Swedish, followed by Germans (11 percent) and Spanish (6 percent).

Table 2. Sample Population Classified by Nationality

\begin{tabular}{|c|c|c|c|c|c|}
\hline Nationality & Persons & $\%$ & Nationality & Persons & $\%$ \\
\hline Swedish & 56 & 14.00 & Portuguese & 9 & 2.25 \\
\hline German & 44 & 11.00 & Indian & 8 & 2.00 \\
\hline Spanish & 24 & 6.00 & Russian & 8 & 2.00 \\
\hline Finnish & 22 & 5.50 & Singaporean & 7 & 1.75 \\
\hline French & 21 & 5.25 & Malaysian & 5 & 1.25 \\
\hline Swiss & 20 & 5.00 & Japanese & 5 & 1.25 \\
\hline Danish & 19 & 4.75 & Chinese & 7 & 1.75 \\
\hline Dutch & 19 & 4.75 & Romanian & 4 & 1.00 \\
\hline New Zealander & 19 & 4.75 & Citizen of Emirates & 4 & 1.00 \\
\hline American & 17 & 4.25 & Indonesia & 3 & 0.75 \\
\hline Australian & 15 & 3.75 & South African & 2 & 0.50 \\
\hline Canadian & 13 & 3.25 & Chilean & 1 & 0.25 \\
\hline Austrian & 12 & 3.00 & Greek & 1 & 0.25 \\
\hline Norwegian & 12 & 3.00 & Guatemalan & 1 & 0.25 \\
\hline Italian & 11 & 2.75 & Filipino & 1 & 0.25 \\
\hline English & 10 & 2.50 & Total & 400 & 100 \\
\hline
\end{tabular}

\subsubsection{Consumer Behavior}

Traveling behavior: Most of them (33.25 percent) traveled with family members, followed by those who traveled with friends (29.50 percent), while the remaining 17.50 percent traveled with tour companies.

Travel decision maker: Most of them (44.75 percent) made a decision to travel by themselves, followed in descending order by those who chose to travel with family members /relatives (28 percent) and those who were accompanied by friends (25.25 percent).

Source of information (media): Most of them (41.55 percent) accessed information from the internet, followed in descending order by those who learned about Thai spas from magazines/newspapers/journals and articles (20.25 percent) and those who heard about them on the radio (1.41 percent) was the least represented.

Most favorite media: Most of them (48.5 percent) favored using the internet, followed in descending order by those who preferred to access information from magazines, newspapers and journals (21.25 percent) and those who preferred to get their information from public relations, documents and brochures (9.5 percent).

Table 3. Respondents Classified by Traveling Behavior and Media through Which Information was Received

\begin{tabular}{lrrlrr}
\hline Traveling Behavior & Persons & $\%$ & Travel Decision Maker & Persons & $\%$ \\
\hline Travel with family & 133 & 33.25 & Self & 179 & 44.75 \\
Travel with friend/s & 118 & 29.50 & Family/Relatives & 112 & 28.00 \\
Use service of company guides & 70 & 17.50 & Friends & 101 & 25.25 \\
Travel alone & 60 & 15.00 & Other & 8 & 2.00 \\
Travel using company services & 12 & 3.00 & & & \\
Other & 7 & 1.75 & & Persons & $\%$ \\
\hline Source of Information & Person & $\%$ & Most Favorite Media & 194 & 48.50 \\
\hline Internet & 236 & 41.55 & Internet & 85 & 21.25 \\
Articles in magazines/newspapers/ & 115 & 20.25 & Articles in magazines/newspaper/ & 38 & 9.50 \\
journals/articles & & & journal & 22 & 5.50 \\
Tour Companies/Travel Agents / & 87 & 15.32 & Public relations/documents/brochures & 20 & 5.00 \\
Public relations documents/brochures & 57 & 10.04 & Tour Companies/Travel Agents & 20 & 5.00 \\
Introduction by friends, relatives & 24 & 4.23 & Advertising billboards & 12 & 3.00 \\
Advertising billboards & 22 & 3.87 & Radio & 9 & 2.25 \\
Radio & 8 & 1.41 & Introduction by friends, relatives & \\
Other & 19 & 3.35 & Other & & \\
\hline
\end{tabular}




\subsubsection{Foreigners' Opinions Concerning Spas}

Importance of spas for travel plans: With regard to foreigners' opinions of spas, they stressed the importance of spas in making their travel plans. It was of sufficient importance that most of them (24.50 percent) preferred to travel where spa services were available or were included. These were followed by 23.75 percent, who stated that, as long as there was a spa somewhere near where they were staying. The third group (21.25 percent) stated that a spa had to be available in the hotel where they were staying (Table 4).

Table 4. Importance Given to Spas in Making Travel Plans

\begin{tabular}{lcc}
\hline Importance to Spa for Travel Plan & Persons & $\%$ \\
\hline Important, but would prefer to travel where spa services are available/are included & 98 & 24.50 \\
As long as there is a spa somewhere near where I am staying & 95 & 23.75 \\
Spa must be available in the hotel where I am staying & 85 & 21.25 \\
Availability of spa is not important. If there is one, it is a bonus. & 39 & 18.50 \\
Extremely important. If no spa available, will choose alternative travel destination & 9 & 9.75 \\
Other & 400 & 2.25 \\
Total & & 100
\end{tabular}

Spa experience compared with other countries: Most of the respondents (39 percent) indicated that spas in Thailand are generally cheaper, followed by 20.75 percent who felt that spas in Thailand offer a higher standard of service. Only 5.50 percent expressed that spas in Thailand offer a lower standard of service (see Table 5).

Table 5. Spa Experience Compared with Other Countries

\begin{tabular}{lcr}
\hline Spa Experience Compared with Other Countries & Persons & $\%$ \\
\hline Spas in Thailand are generally cheaper & 156 & 39.00 \\
Spas in Thailand offer a higher standard of service & 83 & 20.75 \\
Spas in Thailand offer greater variety & 79 & 19.75 \\
Spas in Thailand are generally more expensive & 36 & 9.00 \\
Spas in Thailand offer less variety & 24 & 6.00 \\
Spas in Thailand offer a lower standard of service & 22 & 5.50 \\
Total & 400 & 100 \\
\hline
\end{tabular}

Opinions Concerning Spas in Thailand: Most of the respondents (24.06 percent) expressed that Thai spas are world class, followed by 18.88 percent who felt that spas in Thailand are the best in Asia. This was followed by 15.99 percent who stated that spas in Thailand were nice to visit when on holiday (Table 6).

Table 6. Opinions Concerning Spas in Thailand

\begin{tabular}{lcr}
\hline Opinions & Persons & $\%$ \\
\hline Spas in Thailand are world class & 167 & 24.06 \\
Spas in Thailand are the best in Asia & 131 & 18.88 \\
Spas in Thailand are nice to visit when on holiday & 111 & 15.99 \\
Spas in Thailand need to improve & 97 & 13.98 \\
Spas in Thailand are overrated & 95 & 13.69 \\
Spas in Thailand need to offer higher standards & 93 & 13.40 \\
Total & 694 & 100 \\
\hline
\end{tabular}

\subsubsection{Spa Experiences in Other Countries}

(1) Countries that offer the best spa experience. The majority (55.05 percent) said that Thailand offered the best spa experience, followed by 13.30 percent who felt Indonesia was the best. Only 5.50 percent felt that spa services in Sweden was the third (Table 7). 
Table 7. The Country Offering the Best Spa Experience

\begin{tabular}{|c|c|c|c|c|c|}
\hline The Best Spa Experience & Persons & $\%$ & The Best Spa experience & Persons & $\%$ \\
\hline Thailand & 120 & 55.05 & Canada & 2 & 0.92 \\
\hline Indonesia & 29 & 13.30 & The Dominican Republic & 1 & 0.46 \\
\hline Sweden & 12 & 5.50 & Ireland & 1 & 0.46 \\
\hline Finland & 8 & 3.67 & Italy & 1 & 0.46 \\
\hline USA & 8 & 3.67 & Korea & 1 & 0.46 \\
\hline Australia & 7 & 3.21 & Mexico & 1 & 0.46 \\
\hline India & 6 & 2.75 & New Zealand & 1 & 0.46 \\
\hline Japan & 5 & 2.29 & China & 1 & 0.46 \\
\hline German & 5 & 2.29 & Cambodia & 1 & 0.46 \\
\hline Denmark & 4 & 1.83 & & & \\
\hline Norway & 2 & 0.92 & & & \\
\hline Republic of Estonia & 2 & 0.92 & Total & 218 & 100 \\
\hline
\end{tabular}

(2) Countries have a reputation for offering the best spa experience. Most of the respondents (47.84 percent) said that Thailand has a reputation for the best spa experience, followed by 32.33 percent who felt that the honor should go to Indonesia. Only 5.17 percent expressed the opinion that Australia was the third (see Table 8).

Table 8. A Reputation for the Best Spa Experience

\begin{tabular}{|c|c|c|c|c|c|}
\hline The Best Spa Experience & Persons & $\%$ & The Best Spa Experience & Persons & $\%$ \\
\hline Thailand & 111 & 47.84 & Italy & 2 & 0.86 \\
\hline Indonesia & 75 & 32.33 & Japan & 2 & 0.86 \\
\hline Australia & 12 & 5.17 & The Dominican Republic & 1 & 0.43 \\
\hline USA & 9 & 3.88 & Russia & 1 & 0.43 \\
\hline Sweden & 6 & 2.59 & Singapore & 1 & 0.43 \\
\hline Estonia & 4 & 1.72 & Vietnam & 1 & 0.43 \\
\hline Mozambique & 4 & 1.72 & Finland & 1 & 0.43 \\
\hline India & 2 & 0.86 & Total & 232 & 100 \\
\hline
\end{tabular}

(3) Countries have spas that represent the best value for money. The majority (54.90 percent) said that Thailand's spas offer the best value for money, followed by 26.96 percent who felt that Indonesian spas offered the best deal. Only 2.45 expressed the opinion that Sweden was the third (see Table 9).

Table 9. Has Spas That Offer the Best Value for Money

\begin{tabular}{lrrrrr}
\hline Offer the Best Value for Money & Persons & $\%$ & Offer the Best Value for Money & Persons & $\%$ \\
\hline Thailand & 112 & 54.90 & Hungary & 2 & 0.98 \\
Indonesia & 55 & 26.96 & United Arab Emirates & 2 & 0.98 \\
Sweden & 5 & 2.45 & India & 1 & 0.49 \\
United States of America & 4 & 1.96 & Iraq & 1 & 0.49 \\
Australia & 3 & 1.47 & Mexico & 1 & 0.49 \\
China & 3 & 1.47 & Spain & 1 & 0.49 \\
Republic of Latvia & 3 & 1.47 & Japan & 1 & 0.49 \\
Republic of Estonia & 3 & 1.47 & Malaysia & 1 & 0.49 \\
Vietnam & 3 & 1.47 & & 204 \\
Finland & 3 & 1.47 & Total & 100 \\
\hline
\end{tabular}

(4) Countries have the best spas overall. Most of them (50.70 percent) stated that overall, Thailand has the best spas, followed by 31.46 percent who felt Indonesia had the best. Only 2.35 percent expressed the opinion that Australia was the third (see Table 10). 
Table 10. The Best Spas Overall

\begin{tabular}{|c|c|c|c|c|c|}
\hline The Best Overall & Persons & $\%$ & The Best Spas Overall & Persons & $\%$ \\
\hline Thailand & 108 & 50.70 & Italy & 2 & 0.94 \\
\hline Indonesia & 67 & 31.46 & Republic of Estonia & 2 & 0.94 \\
\hline Austria & 5 & 2.35 & Greenland & 1 & 0.47 \\
\hline Australia & 4 & 1.88 & India & 1 & 0.47 \\
\hline England & 4 & 1.88 & Slovenia & 1 & 0.47 \\
\hline Sweden & 4 & 1.88 & Hungary & 1 & 0.47 \\
\hline Germany & 3 & 1.40 & Spain & 1 & 0.47 \\
\hline Japan & 3 & 1.40 & United Arab Emirates & 1 & 0.47 \\
\hline Mexico & 2 & 0.94 & Finland & 1 & 0.47 \\
\hline United States of America & 2 & 0.94 & Total & 213 & 100 \\
\hline
\end{tabular}

(5) Countries has the best variety of spas. Most of the respondents (48.53 percent) expressed that Thailand has the best variety of spas, followed by 27.45 percent who felt that Indonesia did. Only 4.41 percent believed that United Stated of America was the third (see Table 11).

Table 11. The Best Variety of Spas

\begin{tabular}{lrrlrr}
\hline The Best Variety of Spas & Persons & \% & The Best Variety of Spas & Persons & \% \\
\hline Thailand & 99 & 48.53 & Italy & 3 & 1.96 \\
Indonesia & 56 & 27.45 & Singapore & 3 & 1.47 \\
USA & 9 & 4.41 & China & 1.47 \\
Australia & 8 & 3.92 & Mexico & 2 & 0.98 \\
Sweden & 6 & 2.94 & The Philippines & 2 & 0.98 \\
Japan & 5 & 2.45 & The Republic of Estonia & 2 & 0.98 \\
Finland & 5 & 2.45 & Total & 204 & 100 \\
\hline
\end{tabular}

(6) A must-visit country for spas. Most of the respondents (58.79 percent) described Thailand as a must-visit country for spas, followed by 27.27 percent who felt that it was Indonesia. Only 0.61 percent expressed the opinion that Canada, Iran, Norway, the United States of America, Germany, and Finland deserved to be described in this way (see Table 12).

Table 12. Must-Visit Country for Spas

\begin{tabular}{lrrlrr}
\hline The Best Spas Overall & Persons & $\%$ & The Best Spas Overall & Persons & $\%$ \\
\hline Thailand & 97 & 58.79 & Canada & 1 & 0.61 \\
Indonesia & 45 & 27.27 & Iran & 1 & 0.61 \\
Republic of Estonia & 4 & 2.42 & Norway & 1 & 0.61 \\
Sweden & 4 & 2.42 & United States of America & 1 & 0.61 \\
Australia & 3 & 1.82 & Germany & 1 & 0.61 \\
Ireland & 2 & 1.21 & Finland & 1 & 0.61 \\
Italy & 2 & 1.21 & & 1 & 165 \\
Japan & 2 & 1.21 & Total & 100 \\
\hline
\end{tabular}

\subsubsection{Environmental Considerations}

Most of the respondents (36.75 percent) stated that environmental considerations were very important, and that they felt they had to demonstrate environmentally friendly practices. However, 29.25 percent said that they never thought about it, while 16.75 percent said that it was not important, that the spa experience overrides environmental considerations (see Table 13).

Table 13. Environmental Considerations When Choosing a Spa

\begin{tabular}{|c|c|c|}
\hline Environmental Considerations & Persons & $\overline{\%}$ \\
\hline Very important, they must demonstrate environmentally considerate practices & 147 & 36.75 \\
\hline Never thought about it & 117 & 29.25 \\
\hline Not important, the spa experience overrides the environmental considerations & 67 & 16.75 \\
\hline Extremely important, I consider myself a LOHAS* consumer & 49 & 12.25 \\
\hline Other & 20 & 5.00 \\
\hline Total & 400 & 100 \\
\hline
\end{tabular}

Note: ${ }^{*}$ Lifestyles of health and sustainability 


\subsubsection{Spa Services}

Most of the respondents (60.75 percent) had used spa services many times before, while 39.25 percent were using them for the first time (Table 14).

Frequency of visiting a spa: In all, 29.25 percent visited spas only when on holiday, while 17 percent did so at a convenient time to them, and 15 percent visited a spa only during business trips (Table 14).

Type of spa businesses used: Most of the spas that visitors used fell into the category of resort spas (26.25 percent), while 22.25 percent used hotel spas and only 0.50 percent used cruise ship spas (Table 14).

Table 14. Spa Service Used by Foreigners

\begin{tabular}{lrrlrr}
\hline Spa Service Used & Persons & \% & Spa Type & Persons & \% \\
\hline Number of visits & 243 & 60.75 & Resort Spa & 105 & 26.25 \\
First time & 157 & 39.25 & Hotel Spa & 89 & 22.25 \\
\cline { 1 - 2 } Frequency of Visiting & Persons & $\%$ & Day Spa & 69 & 17.25 \\
\cline { 1 - 2 } Only when on vacation & 117 & 29.25 & Wellness Centers & 33 & 8.25 \\
Only during business trips & 60 & 15.00 & Destination Spa & 19 & 4.75 \\
Monthly & 57 & 14.25 & Club Spa & 13 & 3.25 \\
Fortnightly & 53 & 13.25 & Medical Spa & 12 & 3.00 \\
Weekly & 45 & 11.25 & Cruise Ship Spa & 2 & 0.50 \\
Other & 68 & 17.00 & Other & 58 & 14.50 \\
\hline
\end{tabular}

Design/ Atmosphere: As for the spa's atmosphere, most of the respondents (24.50 percent) favored a natural ambience, followed in descending order by 21.75 percent who favored a Thai-style and 15.75 percent who preferred a resort-style (see Table 15).

Table 15. Atmosphere of Spa

\begin{tabular}{lrr}
\hline Atmosphere & Persons & $\%$ \\
\hline Natural & 98 & 24.50 \\
Thai style & 87 & 21.75 \\
Resort style & 63 & 15.75 \\
Balinese style & 38 & 9.50 \\
Lanna style & 36 & 9.00 \\
Other & 78 & 19.50 \\
Total & 400 & 100 \\
\hline
\end{tabular}

Type of products respondents prefer when visiting a spa: With regard to their most favorite products, most of the respondents (36.25 percent) used proprietary products belonging to the spa service centers. These were followed by 18.75 percent used local/indigenous herbs. Only 2.75 percent stated that used any product as long as it was not local (see Table 16).

Table 16. Type of Products Respondents Prefer When Visiting a Spa

\begin{tabular}{lrr}
\hline Products & Persons & $\%$ \\
\hline I trust the spa to choose the best product & 145 & 36.25 \\
Ones that use local/indigenous herbs & 75 & 18.75 \\
As long as it is from Thailand & 64 & 16.00 \\
Must be an organic product & 60 & 15.00 \\
Only foreign brand products that I know & 15 & 3.75 \\
Any product as long as it is not local & 11 & 2.75 \\
Other & 30 & 7.50 \\
Total & 400 & 100 \\
\hline
\end{tabular}

Spa services used most frequently: With regard to the spa services that respondents used most frequently, 30.64 percent said that they liked a body massage, followed by 22.42 percent liked massage aromatherapy oils, while 12.20 percent liked a back, shoulder and head massage (see Table 17). 
Table 17. Spa Services Used Most Frequently

\begin{tabular}{lrr}
\hline Spa Service Used & Persons \\
\hline Body massage & 246 & 30.64 \\
Massage aromatherapy oils & 180 & 22.42 \\
Back, shoulder and head massage & 98 & 12.20 \\
Herbal massage & 70 & 8.72 \\
Scrubs and Wraps & 56 & 6.97 \\
Facial treatments & 42 & 5.23 \\
Reflexology/Foot/Hand Massage & 38 & 4.73 \\
Beauty Salon Services (Hair, Manicure, etc.) & 33 & 4.11 \\
Water/Heat treatments & 11 & 1.37 \\
Mind / Meditative therapies & 7 & 0.87 \\
Exercise / Activities for health & 6 & 0.75 \\
Healthy Cuisine & 4 & 0.50 \\
Other & 12 & 1.49 \\
Total & 803 & 100 \\
\hline
\end{tabular}

Main reason for choosing this spa: With regard to their reasons for selecting the services of a particular spa, most (15.43 percent) did so in accordance with the quality and standard of the spa's services, followed by 11.02 percent who cited appropriate pricing, while 0.90 percent cited other reasons (see Table 18).

Table 18. Main Reason for Choosing This Particular Spa

\begin{tabular}{lrr}
\hline Main reason for choosing this particular spa & Persons \\
\hline Quality and standards & 154 & 15.43 \\
Appropriate pricing & 110 & 11.02 \\
Service-minded staff & 98 & 9.82 \\
Design/atmosphere & 89 & 8.92 \\
Has a good reputation & 79 & 7.92 \\
Reliability/consistency & 74 & 7.41 \\
Good etiquette and friendly staff & 65 & 6.51 \\
Variety of treatments/therapies available & 61 & 6.11 \\
Public relations/marketing & 57 & 5.71 \\
Consultations & 51 & 5.11 \\
Extensive range of facilities & 49 & 4.91 \\
Cleanliness & 39 & 3.91 \\
Readiness of materials and equipment & 32 & 3.21 \\
Availability of health specialists & 31 & 3.11 \\
Other & 9 & 0.90 \\
Total & 998 & 100 \\
\hline
\end{tabular}

Objectives of using this spa: The objective of most of the respondents (30.75 percent) in the selection of services was to relieve pain in the muscles, followed by 22.50 percent whose goal to improve their health. Only a tiny minority (3 percent) visited a spa for the treatment of some kind of illness (see Table 19).

Table 19. Objective of Using this Spa

\begin{tabular}{lrr}
\hline Objective of Using this Spa & Persons & $\%$ \\
\hline For pain relief & 123 & 30.75 \\
For health/ health promotion & 90 & 22.50 \\
Stress relief & 87 & 21.75 \\
Pampering experience & 78 & 19.50 \\
For treatment/ disease healing & 12 & 3.00 \\
Other & 10 & 2.50 \\
Total & 400 & 100 \\
\hline
\end{tabular}

\subsubsection{Tourists' Satisfaction regarding Service and Environment}

Overall satisfaction: With regard to the respondents' overall level of satisfaction, the mean was $(\overline{\mathrm{x}}=3.82)$. Satisfaction with service $(\overline{\mathrm{x}}=3.88)$ ranked first, followed by satisfaction with environmental elements $(\overline{\mathrm{x}}=3.73)$ (see Table 20). 
Table 20. Mean and Standard Deviation of Overall Satisfaction

\begin{tabular}{lcclc}
\hline Satisfaction & $\overline{\mathrm{X}}$ & S.D. & Levels of Satisfaction & Rank \\
\hline Service/s & 3.88 & .8520 & Satisfied & 1 \\
Environmental Elements & 3.73 & .8943 & Satisfied & 2 \\
Total & 3.82 & .0872 & Satisfied & \\
\hline
\end{tabular}

Service satisfaction: The majority of the respondents were satisfied with the level of service their spa provided: (1) Reception staff, (2) Therapists' friendliness, (3) Therapists' professionalism, (4) Quality of service, (5) Speed of service, (6) Technique of the therapist, (7) Feeling after treatment was finished, (8) Sufficient facilities to meet customer needs, and (9) Value for money of the spa experience and (10) Services/therapies provided in a timely manner. The majority of the respondents were neither satisfied nor dissatisfied with the level of service in terms of: (1) The information they received and whether it enhanced their visit to the spa and (2) Sufficient staff to meet customers' needs.

Table 21. Opinions Concerning Spa Services

\begin{tabular}{llll}
\hline Service/s & $\overline{\mathrm{X}}$ & S.D. & Levels of Satisfaction \\
\hline Reception staff & 4.12 & .0779 & Satisfied \\
Therapists' friendliness & 3.83 & .7040 & Satisfied \\
Therapists' professionalism & 4.05 & .8332 & Satisfied \\
Quality of service & 4.12 & .7794 & Satisfied \\
Speed of service & 4.06 & .7704 & Satisfied \\
Technique of the therapist & 3.87 & .7970 & Satisfied \\
Feeling after the treatment & 3.86 & .7961 & Satisfied \\
Sufficient facilities to meet customers 'needs & 3.91 & .8262 & Satisfied \\
Value for money of the spa experience & 3.90 & .9033 & Satisfied \\
Services/therapies provided in a timely manner & 3.80 & .8651 & Satisfied \\
Consultation with others was the information used to enhance your spa visit & 3.49 & .8779 & Neither satisfied nor dissatisfied \\
Sufficient staff members to meet customers' needs & 3.50 & .9499 & Neither satisfied nor dissatisfied \\
Total & 3.88 & .8520 & Satisfied \\
\hline
\end{tabular}

Environmental satisfaction: The majority of the respondents were satisfied with the following: (1) Elegance/ atmosphere, (2) Location, (3) Cleanliness, (4) Convenience, (5) Facilities provided, (6) Parking. The majority of the respondents were neither satisfied nor dissatisfied with the level of (1) Accessibility and (2) Signage - making it easy to find the spa (see Table 22).

Table 22. Opinions Concerning the Environmental Elements Spa

\begin{tabular}{lccc}
\hline Environmental Elements & $\overline{\mathrm{X}}$ & S.D. & Levels of Satisfaction \\
\hline Elegance / Atmosphere & 4.03 & .7941 & Satisfied \\
Location & 3.98 & .8684 & Satisfied \\
Cleanliness & 3.86 & .8665 & Satisfied \\
Convenience & 3.78 & .8725 & Satisfied \\
Facilities provided & 3.72 & .9185 & Satisfied \\
Parking & 3.57 & .8646 & Satisfied \\
Accessibility & 3.48 & .9173 & Neither satisfied nor dissatisfied \\
Signage - making it easy to find the spa & 3.47 & .8666 & Neither satisfied nor dissatisfied \\
Total & 3.73 & .8943 & Satisfied \\
\hline
\end{tabular}

\section{Development Strategies}

These are composed of demand strategies relating to management, market planning, competition, marketing and public relations, successful spa factors, and the export market. On the other hand, supply strategies involve spa and standard development, including export promotion. In addition, service and customers' satisfaction are also included. However, the strengths of this business were the use of various natural herbs, Thailand's reputation for massage, the availability of natural hot springs, polite manners, and good service. Therefore, these strengths constitute the foundation of this sector's sales strategies. Conversely, the weak points of this business, such as communication problems, economy and political crisis, and shortage of skilled human resources. 


\section{Implications and Recommendations}

Public policy implications are:

- An integral promotional central agency should be established.

- Determination of service standard should be established.

- Marketing public relation should be made aggressively.

- Spa personnel should be developed to meet the standard.

- Coordinating centers should be established.

- The promotion of health-related tourism should be made a continuous policy at the national level.

- Marketing research should be conducted.

- A universal standard governing spas should be adopted.

- Centers for learning of foreign languages should be set up with regard to the spa business.

- The public sector should provide the requisite coordination and determine clear directions.

- Spa personnel develop to have the knowledge and capacity to meet the international standards.

- Public relations initiatives should be undertaken with regard to tourist groups.

Recommendations are to solve the obstacles. They are natural and man-made disasters, a lack of qualified and educated human resources, the potential and readiness of overseas franchises, communication problems, a lack of cooperation, the need for marketing initiatives and public relations, a lack of clarity and continuity with regard to promotion, the high level of competition etc. In this regard, it is suggested that an integrated and centralized promotional agency be established, that services be standardized, centers be set up for the purpose of coordination and foreign language learning, aggressive marketing and public relations campaigns be launched, programs devised for the professional development of spa personnel, the requisite market research conducted, etc.

\section{Acknowledgements}

I would like thank the many individuals who helped make this study possible. My sincere thanks to all those spa entrepreneurs and foreign tourists for the many hours spent helping us conduct interviews, write stories, and think about the implications of those stories. Also, my sincere thanks go to Ms. Yuvadee Nirattakun, Director of Thai Tourism Marketing Research, and Mr. Bunsert Jatchavala, Attending Physician, MD., Doctor of Chao Phya Hospital, have truly excelled as my research advisors. Special thanks must go to Mr. Santichai Euachongprasit, Deputy Governor for International Marketing who was unstinting in the time and support he devoted to ensuring that the research project was completed. Special thanks must also go to Associate Professor Dr. Montree Piriyakul, who provided a very special sort of help with his wealth of academic knowledge. In addition, I wish to express my appreciation to Professor Dr. Sivimol Wongvanit, Mr. Pradech Phayakvichien and Dr. Therdchai Choibamroong who worked as members of my academic committee. In addition, we have been assisted by many dedicated, talented people. We can't possible thank all of them here, but we do wish to express our appreciation to those whose help has made this research possible.

\section{References}

Boonroong, Wosmon. (2007). Demand for Using Spa Service in Bangkok. (Master degree thesis in Economics). Ramkhamhaeng University, Bangkok.

Department of Export Promotion, Data Service Center. (2008). Guideline of Spa Business Development. Searching on August 26, 2008, from http://www. depthai.go.th

Institute of Professional and Thai Culture Encouragement, Spa. (2008). Spa Business in Thailand. Searching on May 20, 2008, From http://www. thaispanet.com.

Mhunkham, Jeerasak. (2008). Strategic Planning of Spa Business. (Master degree thesis in Economics). Ramkhamhaeng University, Bangkok.

Pothisathian, Sukanya. (2005). Health Promotion of City People in Health Service Places: Case Study of Spa Service Users in Bangkok. (Master thesis in Liberal Arts). Ramkhamhaeng University, Bangkok. 